\title{
The role of mites in the construction and weathering of siliceous biospeleothems
}

\author{
María J. López-Galindo \\ University Institute of Geology Isidro Parga Pondal, University of Coruña, 15071, A Coruña, Spain
}

\begin{abstract}
Acarines are well-documented as formative elements in the biocenosis of soils. However, their role in the construction and weathering of siliceous speleothems has received very little attention in previous research. The present study describes different groups of cavities (nesting/molting sites) excavated by these organisms in the surface of siliceous speleothems that are deposited in the fissures between various granite boulders in Southern Spain. There is evidence that there are immature stages that would survive the heat and drought of summer in the form of small larvae, or euedaphic nymphs, in the soil. This study provides the first description of how this particular variety of organism, typical of the ecosystems established on this type of speleothem, develops a specialized ecological niche that concurrently mobilizes and modifies a significant portion of the polymineralic grains that form the primary stage of the speleothem.
\end{abstract}

Keywords: acari, bioconstruction, granite boulder, quaternary, siliceous speleothem

Received 26 May 2018; Revised 13 October 2018; Accepted 13 October 2018

Citation: López-Galindo M.J., 2018. The role of mites in the construction and weathering of siliceous biospeleothems. International Journal of Speleology, 47 (3), 407-415. Tampa, FL (USA) ISSN 0392-6672 https://doi.org/10.5038/1827-806X.47.3.2208

\section{INTRODUCTION}

Acarines are among the most ancient of terrestrial animals, with fossils dating from the beginning of the Devonian period, some 400 million years ago (Norton et al., 1988). Presently, they constitute a highly diverse group distributed extensively around the world. The wide variability of the environments in which they are found results in the high diversity of the species. Our main point of interest lies in the role of mites as modifying elements of siliceous speleothems, and in the study of these organisms as common components of the biocenosis of cavities formed in magmatic rocks around the world (Vidal et al., 2015). Nevertheless, the data obtained in the present study for this specific locality cannot be generalized to other caves in pseudokarstic environments, given that the species of acarine and the type of burrows it creates are highly particular, and mentions of them do not exist in prior research. While it is true that different mites of varying species occur on siliceous speleothems associated with felsic magmatic rock caves in other locations in the world, currently citations referencing them are rare (Vidal Romani et al., 2015). However, there are numerous mentions that do exist for limestone or even quartzite caves (Lundberg et al., 2010). In any case, these mentions solely include these organisms as a part of the inventory of troglofauna in the endokarst; their influence in the development of these deposits is rarely considered. Generally, the surface of speleothems is used by mites as a physical support for their movements as part of their normal activity in the subterranean environment, but the cases presented here demonstrate how acarines also clearly interfere with the speleothems' development, causing changes to their superficial morphology. Additionally, the life cycle of these organisms is closely linked to dampness and ambient temperature, and therefore, they can aid in reconstructing the formational stages of this type of deposit.

But not only acarines are part of this microecosystem, there are also other organisms such as bacteria, cyanobacteria, fungi, testate amoebae, diatoms, collembolans, etc. Some of them produce organic acids during their metabolism, which could facilitate the dissolution of quartz, which will be argued in the discussion section. As for the precipitation of dissolved silica, this takes place thanks to fundamentally two processes: one chemical by supersaturation, due to evaporation (Wray, 1997); and another biological in which $\mathrm{SiO}_{2}$ precipitates on some microorganisms or is incorporated into their organic structures (Kröger et al., 1999).

This type of speleothem can be formed in the partially-open fissure systems of felsic rock massifs, developing in caves of varying dimensions, ranging 
from a few centimetres to dozens of meters in size. The defining characteristic of these caves is their protection both from runoff and the direct impact of raindrops. The presence of water in the subterranean system is caused by tiny infiltrations (seeping or trickles) in smaller cavities and/or, in the case of cavities of greater dimensions, is a result of the condensation of atmospheric moisture present in the cave (Sauro, 2013; Vidal et al., 2015). These siliceous deposits are composed of three types of elements: (1) inorganic, due to physico-chemical disaggregation of the rock (detritic fraction); (2) biological, corresponding with the microorganisms which live in the underground environment and their fossil remains; and (3) biomineral (Westall \& Cavalazzi, 2011), that is, the minerals formed by the interaction between the inorganic mineral substratum and metabolic products generated by troglobionts. In magmatic rock caves, $\mathrm{SiO}_{2}$ is the essential component of some biominerals (e.g., biogenic silica forms the frustules of the diatoms and the plates of the testate amoebae).

The present study describes the detection of mites and/or their remains and evidence of their everyday activity. These include fragments shed during molting as well as the burrows excavated by these organisms, exceptional for their uniqueness among acarines. These niches are circular, micrometric and pierce the polymineralic grains of the primary speleothem. Furthermore, they feature a type of cover sealed with silk threads. All samples in this study correspond with the siliceous speleothems formed in the fissures between large granite boulders in Las Jaras, near the city of Cordoba in Southern Spain.

\section{GEOLOGICAL AND GEOMORPHOLOGICAL CONTEXT}

The samples of siliceous speleothems, in which these types of organisms and burrows appear, were taken from the post-Hercynian granite which forms the Cerro de Pedro López (Fig. 1), a rocky hill adjacent to the residential area of Las Jaras, situated some 15 $\mathrm{km}$ northwest of the city of Cordoba, Spain (Fig. 1). This location was one of the sampling points of a more general project (López-Galindo, 2013) that aimed, as one of its objectives, to compare this type of speleothem in the north and south of Spain under different climatic conditions. In this case, the study area is restricted to the granite intrusion of Las Jaras because it is in this location that this unique species of mite appears. This area displays a Csa temperate climate, with hot dry-summers, an average annual precipitation of $760.7 \mathrm{~mm}$ and an average annual temperature of $15.68^{\circ} \mathrm{C}$. Its vegetation is typical of Mediterranean forest, although the stone pine (Pinus pinea $L_{\text {.) }}$ is the dominant species due to reforestation.

The granite described in this zone belongs to the Villaviciosa de Córdoba-La Coronada Magmatic Alignment, located in the northern part of the OssaMorena Zone on its border with the Central Iberian Zone (Apalategui et al., 1990) (Fig. 1A). It displays a medium-grained hypidiomorphic texture, and in the southern part of the intrusion, the host rock is comprised of Cambrian sediments, which feature a small metamorphic aureole in the area of contact. The form of the intrusion and the lack of tectonic structures indicate post-Hercynian granite, whose
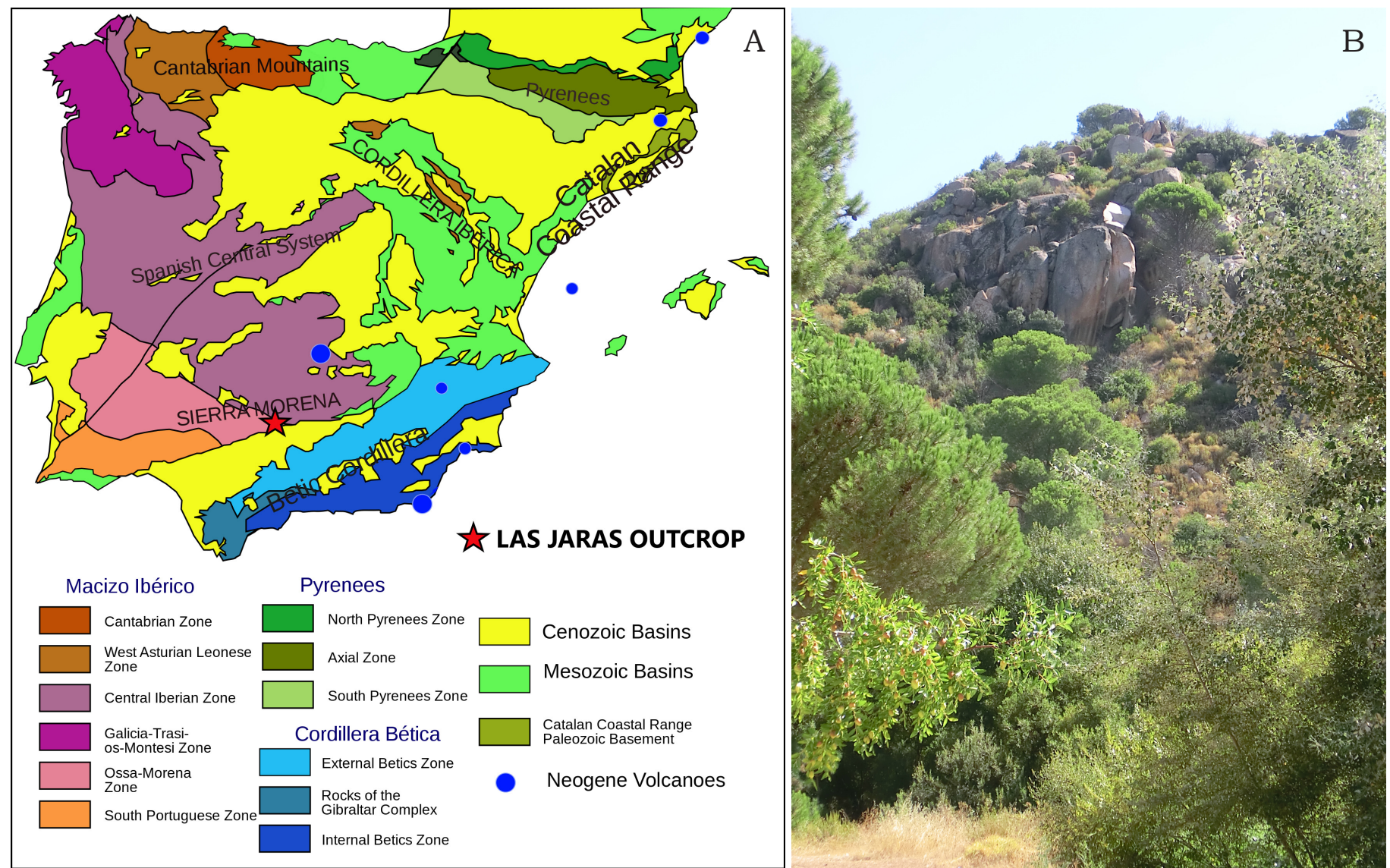

Fig. 1. A) Las Jaras geological location map (modified from Geological units of the Iberian Peninsula CC BY-SA 3.0); B) General view of the Cerro de Pedro López. 
specific texture, becoming aplitic on the edges, would suggest a rock formed at a shallow depth through rapid cooling. Its principal components, which will later make up the small polymineralic grains of the primary speleothem, are perthitic orthoclase, quartz, biotite and zoned plagioclase; as accessory minerals: zircon, apatite, and fluorite; and as secondary minerals: kaolin, sericite, chlorite, epidote, sphene, allanite, and carbonate (Ramirez et al., 1973). These granites form very gentle reliefs and are the constituent elements of the residual rocky hills that crop out from a layer of sandy regolith. The spheroidal weathering has divided these granites into boulders, causing castle koppies like the one showed in Fig. 2A. Every fracture or alcove located among these boulders is susceptible to display this type of speleothem, especially when they are protected from the direct impact of raindrops and insolation. However, these cavities are of decimetre dimensions so they are exposed to varied amounts of sunlight (photic conditions) (Fig. 2B). These twilight zones have a high degree of relative humidity for a period of time but hot and dry conditions in the long Mediterranean summer. The siliceous speleothems can appear indistinctly on the ceiling, wall or floor of the cavity (Fig. 3). They can also be present in a large array of cavity types, from the large caves sensu stricto to small joints, including all kinds of tafoni and rock shelters.
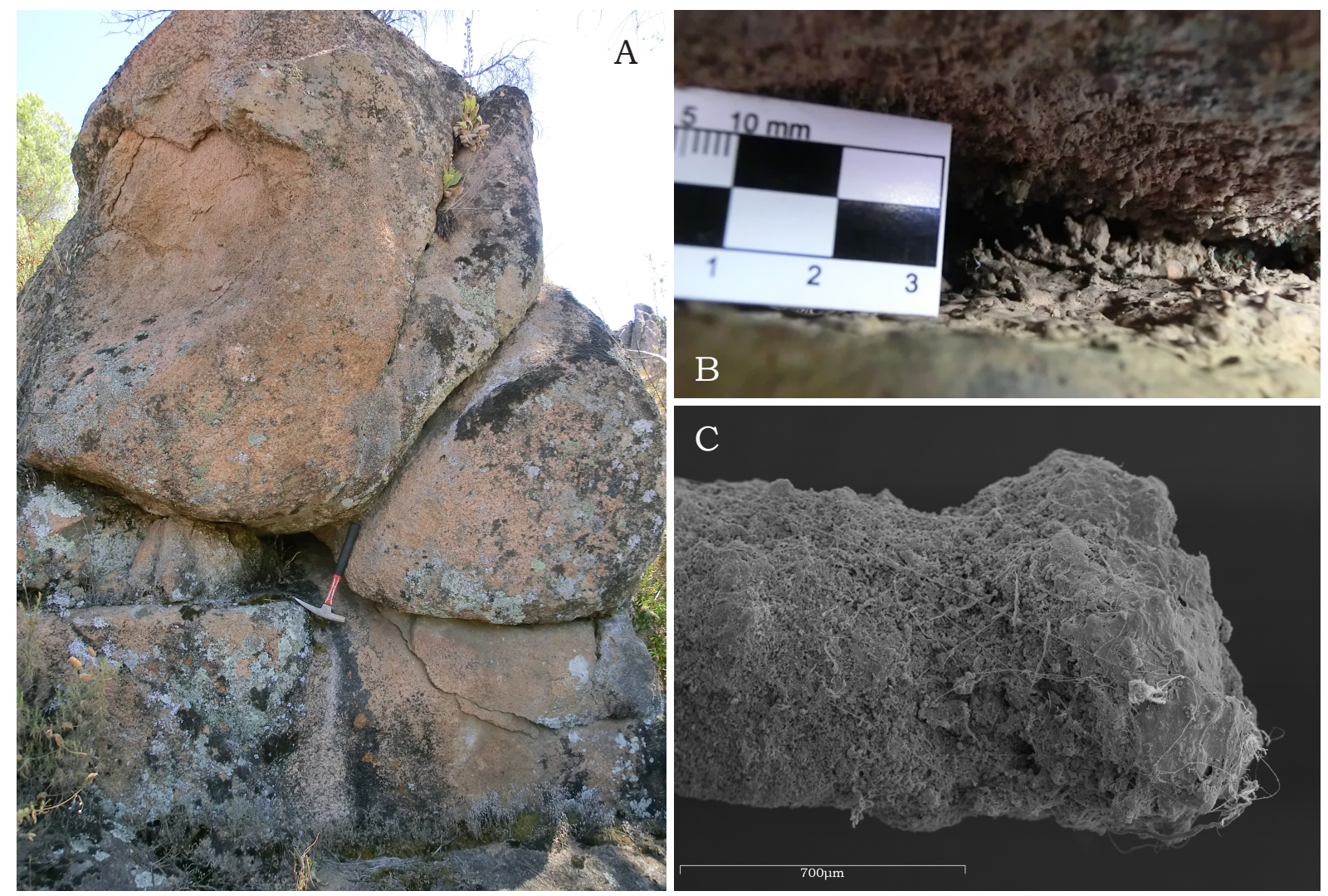

Fig. 2. A) Castle Koppie located in the area called Las Jaras (Córdoba, Spain); B) Siliceous speleothems deposited in the crevices between the granite boulders; C) Primary speleothem partially covered by opal (scanning electron microscope).

\section{MATERIAL AND METHODS}

The siliceous speleothems, in which the aforementioned mites and remnants of their activity appeared, were all systematically sampled from the cavities between the granite boulders (Fig. 2B) of the hill Cerro de Pedro López (Fig. 1B). The samples were taken at the end of August corresponding with the first rains of the hydrological year and with the beginning of the descent from the high summer temperatures. The number of samples and their location in the granitic intrusion were randomly established according to the characteristics of each outcrop. It was decided to take a total of 19 samples, distributed in 7 points of the hill. The location was then established using GPS, the different outcrops and speleothems were photographed, and specimens of both the host rock and the deposits were collected. The samples, placed in individual bags, were duly marked with the name of the place of origin, a serial number corresponding to each sampling location, and a letter determining the order of the samples taken. Subsequently, any relevant peculiarities were noted, such as the date of sampling, the date of last precipitation, as well as the position in the cave where they were taken (wall, floor or ceiling), including a locational sketch. Lastly, to prevent their physical deterioration, the samples were suitably protected in specimen containers for their transport to the laboratory. Following the field sampling, the boxes of samples were properly classified according to the different outcroppings and sampling locations and stored under the initials LJ (Las Jaras) in the University Institute of Geology Isidro Parga Pondal at the University of Coruña, in Spain. The speleothems were subsequently studied in the laboratory using a Nikon SMZ 1500 stereoscopic light microscope equipped with a Nikon DS-Fi1 digital camera. This allowed the samples to be viewed in their natural colour, and the areas of highest interest to be selected for both a thorough examination with the 
SEM (JEOL JSM 6400) and an elementary chemical analysis via backscatter X-ray imaging (Vidal-Romaní et al., 2013).

\section{RESULTS}

\section{Siliceous speleothems}

A wide variety of very small siliceous speleothems, with maximal dimensions measuring in the centimetres, were sampled in the studied area. They have a detrital and polymineralic internal constitution and host different life forms on their surface. Some of them are partially covered with opal that overlies the polymineralic grains (Fig. 2C) and the microorganisms, or their remains, encountered in its progression.

All of the sampled speleothems belongs to two main morphogenetic groups (Fig. 3): (1) speleothems produced by water surface flow, (2) speleothems originated by condensation/evaporation. In the first group, the mineral deposits are flowstone type (Fig. 3C), showing a certain control by the flow direction; in the second group, the speleothems grow in any direction from the ceiling, wall or floor of the cavity and they display different morphologies such as coralloid speleothems (Fig. 3A), false stalactites (Fig. 3B), false stalagmites (Fig. 3D) and gours (Fig. 3E). All of them are not formed by dripping or stagnation (LópezGalindo, 2013), but by condensation/corrosion and silica diffusion from the host rock porosities.

Under an initial examination by stereomicroscope, some of the samples, mainly the labelled as LJ-5D and taken from the underside of one of the granite boulders that make up the castle koppie of Fig. 2A, display a series of unique acarine-built cavities, on which this work focuses.
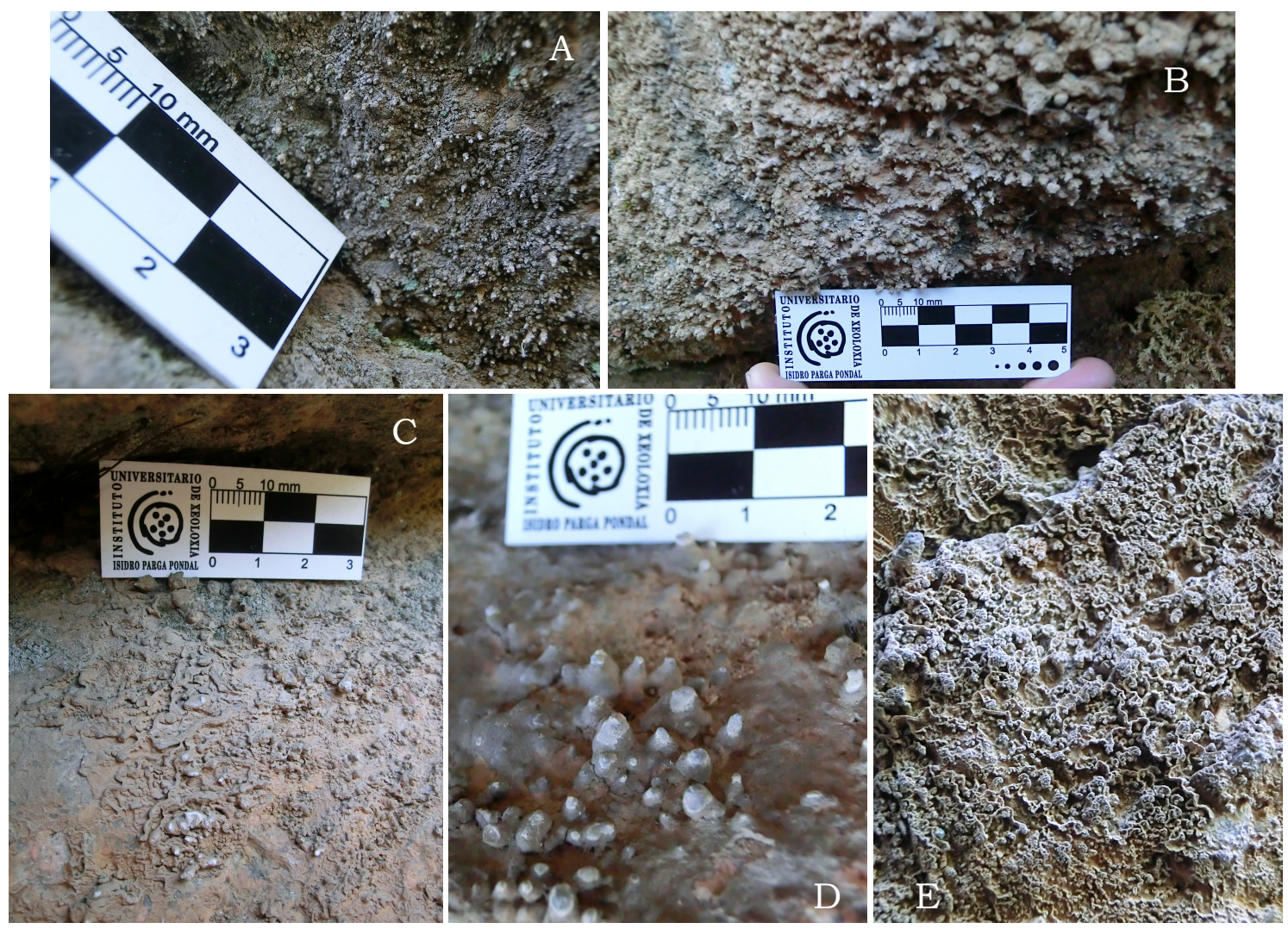

Fig. 3. A) Coralloid speleothem; B) False stalactites; C) Flowstone; D) False stalagmites; E) Gours.

\section{Exuviae and cavities}

The aforementioned groups of acarine-built cavities were found in a subset of the studied samples, specifically those displaying a superficially sandy texture, appearing together on a honeycomb-patterned niche (Fig. 4A) on flowstone speleothems with associated microgours and cylindrical speleothems (Fig. 3C). These niches, elaborated by some species of arachnids, display a type of cover with a protective surrounding ridge created by a combination of silk threads and sand grains (Fig. 4B). The hole can be either covered or open, allowing a view into its interior where organic remains can occasionally be seen. There are various groups of between 5 and 40 cavities each, tightly packed together in a similar direction and formed on the most sunken areas of the speleothem. Each one of these niches, of a semi-circular contour, has interior dimensions ranging between 294 to 347 microns along the major axis and between 183 to 245 microns along the minor. The edges, which project notably from the surface of the speleothem, have a thickness of 32 to 96 microns. The side met by the cover occasionally rises to form a ridge, which can be bifurcated, reaching up to 320 microns in height (Fig. 4C). The remains of a very fine and delicate material, torn in the middle, are occasionally visible in the interior of these cavities (Fig. 4E) and, when viewed in natural colour through the stereomicroscope, they have a pearly appearance on its outer side and black on the inner.

\section{DISCUSSION}

Macroscopic and microscopic observations of the speleothems allow us to outline a genetic model and to better understand the role of microorganisms, 

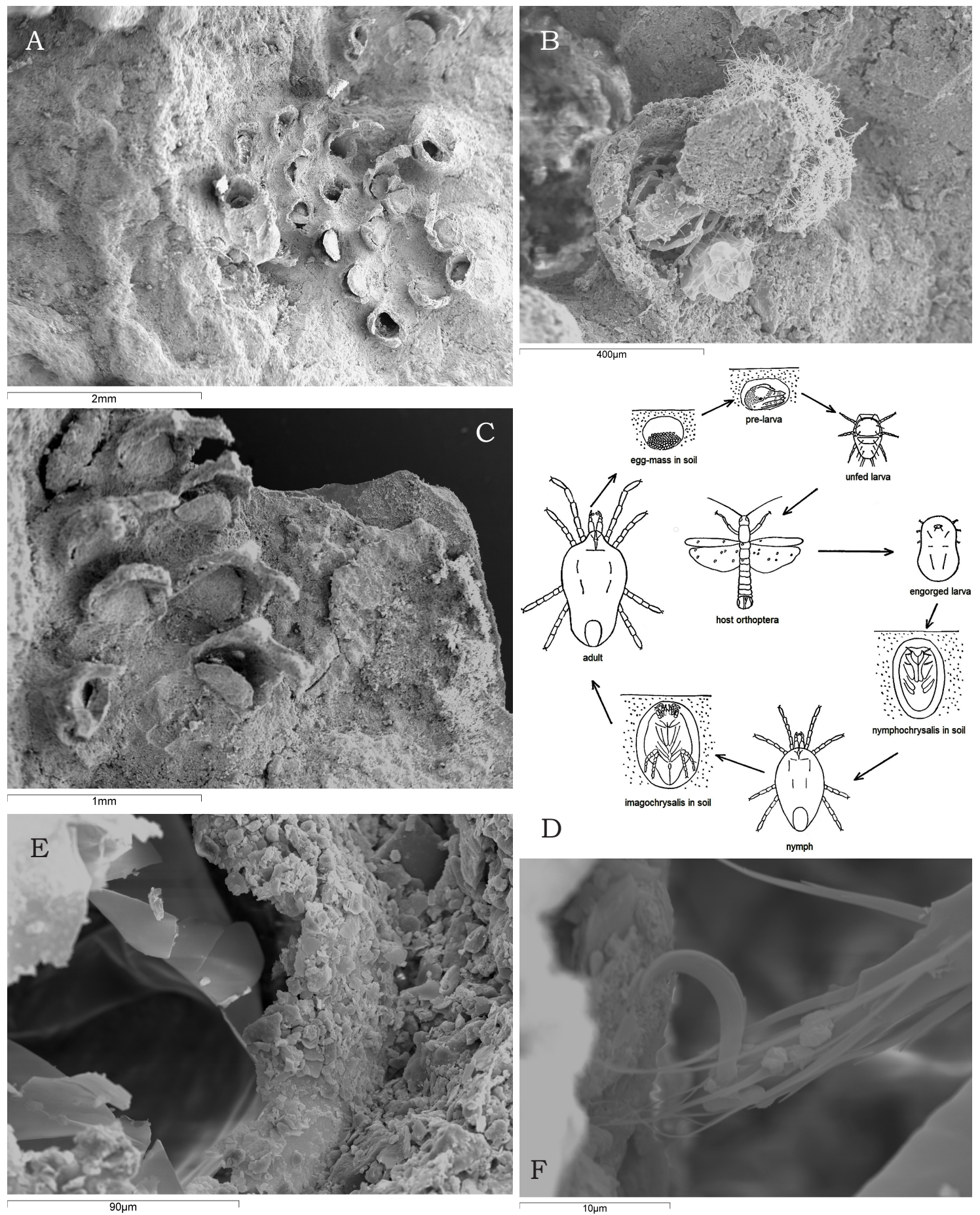

Fig. 4. A) Nesting site of acarines excavated in the primary speleothem; B) Cavity with cover sealed with silk threads, and acarine molt in its interior; C) Acarine-built cavities with bifurcated ridges; D) Life cycle of Eutrombidium rostratus (modified from Evans et al., 1961); E) Remains of a very fine and delicate material in the interior of the cavities;

F) Single claw articulated with the pretarsus in the form of a hook.

particularly of mites. The following genetic stages can be identified:

Detrital Stage: Speleothem formation begins with rainwater that slowly drips on the surface of the outcrop and partly infiltrates the rocks' fissure system until reaching the cavities. As it travels, it collects a series of heterometric, polymineralic grains that are carried in the form of suspension (slurry) and subsequently deposited along the walls, floor or ceiling of the cave (Fig. 3), forming granular detrital accumulations (primary speleothems) with porous texture. Because of the fact that these speleothems grow under these small cavities, in the event of strong rainfalls, they remain protected by high energy surface flows that could erode them and impede chemical precipitation (Vidal et al., 2010).

Biotic Stage: In this small type of cavity, where sunlight is partially received, life begins to colonize this previously inhospitable site, starting with photosynthetic organisms, cyanobacteria, algae and lichens that require low light conditions (Whitton, 1992; Moulds, 2007; Walker \& Moral, 2011). These are succeeded subsequently by forms of greater complexity, in this case, consumers such as testate amoebae, collembolans, and acarines that evolve the ecosystem towards a state of greater maturity. The appearance of organic remains leads to a bloom of fungi and bacteria, which work to decompose and 
transform the matter. Until now, many researchers had recognized the predominantly microbial origin of siliceous speleothems (e.g., Forti, 1994; Urbani, 1996; Léveillé et al., 2000; Willems et al., 2002), but only a few had provided information on their microbial composition (Wray, 1999; Aubrecht et al., 2008; Northup et al., 2011, 2013; López-Galindo, 2013; González et al., 2013; Ghezzi et al., 2017).

Mineral Stage: On this medium, populated by organisms that live in the porous system, the fundamental next step in the development of speleothems with opal-A is the silica dissolution contained in the minerals, particularly quartz and feldspars that make up the felsic rock (Vidal et al., 2010). However, the dissolution of quartz is known to be minimal unless $\mathrm{pH}$ levels reach values higher than 8 (Krauskopf, 1967), which is not expected for rainwaters flowing on these rock surfaces. The living organisms described in the previous stage, thus, could come to the forefront of the process. According to some authors (Beckwith \& Reeve, 1969; Silverman \& Munoz, 1970; Surdam \& MacGowan, 1987), they could carry on the biological dissolution of quartz, through the action of their metabolicallyproduced organic acids. The role of organic matter and microorganisms in triggering quartz dissolution has also been suggested by Hiebert (1992) and Barton et al. (2009). In standard conditions with neutral $\mathrm{pH}$, they could dissolve the quartz eight to ten times faster than pure water (Bennett et al., 1988; Bennet, 1991). Nevertheless, Wray \& Sauro (2017), supporting themselves in different studies (Silver, 1962; Fein \& Hestrin, 1994; Wiegand et al., 2004; Huber \& Garcia, 2011), affirm that because of the great difficulties in setting up reproducible experiments due to problems of filtration of organic acid-rich waters, there is still not a clear understanding on the real effects of these organic compounds on quartz solubility. Likewise, Lavoie et al. (2010) confirm that the involvement of microbes in the formation and weathering of silica speleothems is an area open to study.

In any case, the silica hydrogel $\mathrm{SiO}_{2} \cdot \mathrm{nH}_{2} \mathrm{O}$, organically or inorganically produced, moves over the speleothem until, as evaporation increases (Wray, 1997), it precipitates in the form of amorphous opal (Fig. 2C). This opal covers, to varying degrees, the surface of the polymineralic clasts accumulated in the first stage and can fossilize any living organisms and their remains developed in the second stage. In subsequent stages with elevated moisture levels, in which the circulation of water through the fissure system is reactivated, the amorphous silica, being more soluble than the crystalline quartz (Alexander et al., 1954) and easily weathered by the biochemical activity of bacteria, algae, fungi and lichens (Ehrlich $\&$ Newman, 2008) re-forms into an opal gel that reprecipitates and covers the surface of the speleothem in thicker layers (López-Galindo, 2013). After this, acarines contribute to the mechanical bioweathering of the rock, being able to modify the speleothem surface, while increasing its porosity and creating specific patterns (Fig. 4A) at the microscale. However, there are no evidences that they would contribute to the chemical mobilization of silica for constructing the speleothem.

Mites carve their niches in the amorphous silica substrate in a similar way that some species of arachnids create their trapdoors. Among all the hollows found, there is a group of five, in which two of the acarine molts (ecdyses) are observed. One of them belongs to a specimen who left one of the uncovered niches (Figs $4 \mathrm{~B}$ and $5 \mathrm{~B}$ ) and the other is in a small space between one of the speleothems and the edge of another of these holes (Fig. 5A).

Normally the observable characteristics of these specimens would be decisive in their identification; however, as seen in Table 1, no species exists in prior research that displays each and every one of the noted characteristics. This supports the idea that the mite in question could be a new, previously undescribed species.

On the one hand, examining the first of the aforementioned ecdyses, a single claw is observed on one of its legs, articulated with the pretarsus in the form of a hook (Fig. 4F). Although acarines are normally characterized by a pair of claws and/or a central empodium (Krantz, 1986), many species display modifications to these structures as adaptations to different varieties of habitats. Several species of the genus Eutrombidium are monodactyl; moreover, some organisms of this genus are known for digging holes in the soil for egg-laying or to perform their molting. Furthermore, the development of particular instars during the life-cycle of some species of this genus takes place in the soil. The adult female lays her eggs in small holes, where the pre-larva develops. Later, it becomes a larva that emerges in search of food and then buries itself in the soil again to form a nymphochrysalis, which afterward develops into a nymph. It re-emerges and buries itself once again, where it converts into an imagochrysalis. Finally, at the end of its development, it leaves the burrow as an imago, or adult (Fig. 4D) (Evans et al., 1961; Evans, 1992). On the other hand, Eutrombidium do not have the capacity to secrete silk threads; whereas, acarines from the family Rhagidiidae are characterized by this ability, and are also known to make nests in the soil for their molts. Furthermore, the majority of the species of this family are characterized by season-dependent life cycles and, in a few species, the populations survive the heat and dryness of summer as small larvae or euedaphic nymphs in the soil (Zacharda, 1978). In the case of the honeycomb-patterned niches (Fig. 4A), found in the speleothems in the present study, it is visible that some remain closed while others are open and empty. One of them displays signs of being opened by the immature acarine that occupied its interior, and just outside it, a molting phase takes place. This is a peculiar shedding in which the tegument splits along a circular line of dehiscence from one side of the organism to the other, outlining all its body (PérezÍnigo, 1993) (Fig. 5B). The time in which the samples were taken, at the end of summer, could indicate that it was a species from the Rhagidiidae family, just at the end of an aestivating stage. Furthermore, the remains that appear here have a single claw (Fig. 4F), 

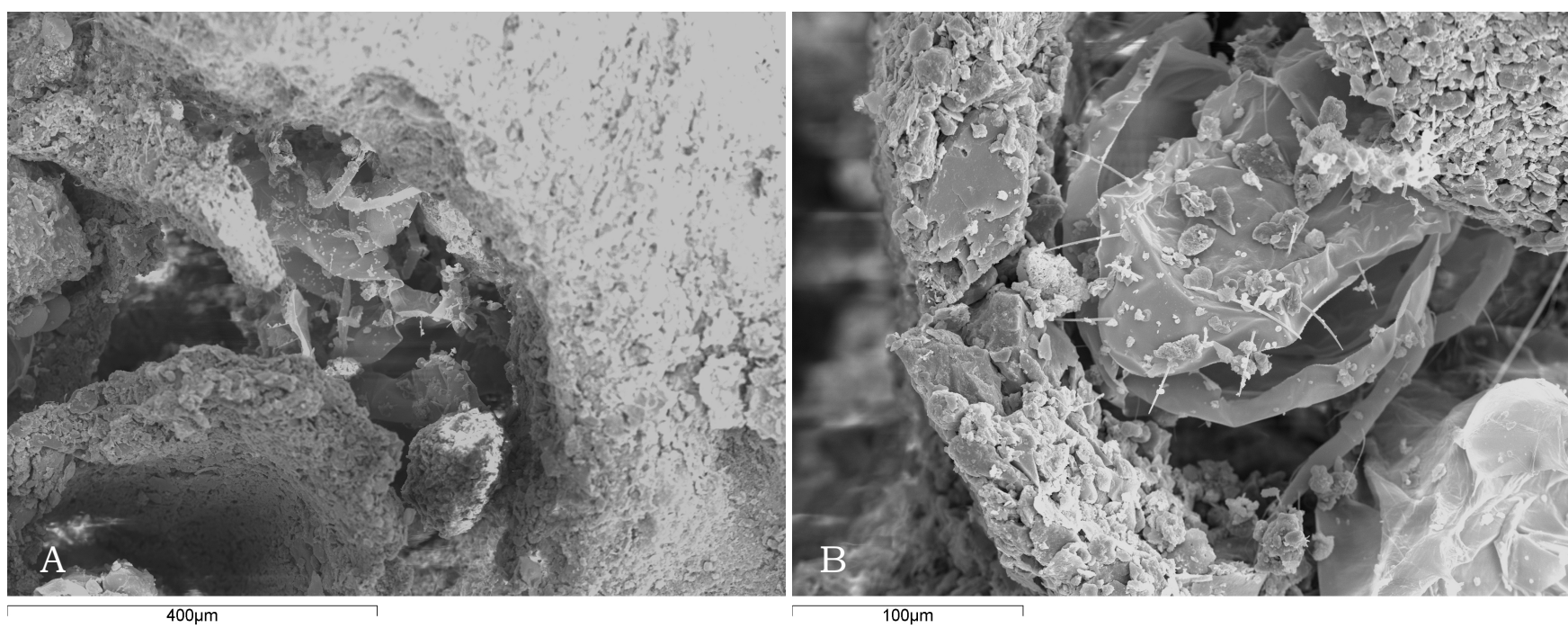

Fig. 5. A) Acarine ecdysis. Detail: collembolan scale attached to the body of the mite; B) Line of circular dehiscence that splits the tegument and permits the molt. Setae and dermal glands.

which is not a trait of this family. Another possibility is that it was the remains of a nymph of an oribatid mite (oribatida) as most of them have a single claw in immature stages, but acarines of this family could not have excavated this type of burrow in the substrate, nor have secreted the silk threads that form the seal for its cover. Taking all of that into account, it could follow that these mites find themselves in these niches in search of food or for other purposes, without being responsible for their excavation. However, this last appears improbable, given that the size and form of these cavities are perfectly fitted to the body of the animal.

If the arrangement of these niches (Fig. 4A) is considered, it can be hypothesized that they could be a nesting site. In that case, the fine and delicate material found in some niches (Fig. 4E) would possibly be the chorion of an acarine egg. Starting as eggs in the soil, different instars in the ontogeny of the mite develop over time. Egg laying takes place in an area called the "nest", where the female can remain, displaying a type of aggressive behaviour that can be interpreted as defense or protection of her eggs. Indeed, this could be the reason for the presence of the second mite, located between a speleothem and one of the niches of the nesting site. Moreover, a collembolan scale is visible on one of its legs, as seen in Fig. 5A, which would confirm predation as one of the alimentary habits common among these acarines. Summers and Witt (1972) affirm that when predation takes place, the remains of prey can adhere to the body of the acarine for some time.

Other observable characteristics on the surface of these molts are: (1) the setae, which, while not permitting the reconstruction of its chaetotaxy, do confirm it as acarine ecdysis, and (2) the dermal glands (Fig. 5B), which together with their duct open through a pore at the surface of the cuticle. In some types of mites, each gland consists of a pair of large glandular cells and several smaller cells that form the glandular duct. The function of these glands could be for secreting the cement layer of the cuticle several hours after the molt, participating in the formation of the wax layer; or lubricating the body surface of the acarine. More recently, these glands have been considered the place where the secretion of sexual, alarm and aggregation pheromones occur (Leal et al., 1989).

Table 1. Observable characteristics of the studied individuals and the types of organism that could present them.

\begin{tabular}{|l|c|c|c|}
\cline { 2 - 4 } \multicolumn{1}{c|}{} & Silk & Molting nests & monodactyl \\
\hline Fam. Rhagidiidae (some species) & $\mathrm{x}$ & $\mathrm{x}$ & \\
\hline Genus Eutrombidium (some species) & & $\mathrm{x}$ & $\mathrm{x}$ \\
\hline Oribatid nymph & & & $\mathrm{x}$ \\
\hline
\end{tabular}

\section{CONCLUSION}

The acarines, described in this article, modify the surface of siliceous speleothem, in cavities within granite rocks, leaving features previously undescribed in literature. This is the first time a study has been made of this variety of deposits and its relationship with the organisms involved in its bioconstruction and bioweathering. While, unfortunately, a more accurate identification of the acarine species associated with these remarkable burrows has not been possible, the importance of the discovery of these niches, as well as the fact that these mites likely constitute a previously undescribed species, must be emphasized. Although it is normal to observe the presence of acarines and their remains on speleothems, it is the first time that a certain variety of organism, from among all those that inhabit this microecosystem (bacteria, amoebas, algae, fungi, lichens, collembolans, etc.), has been discovered to construct a series of receptacles, piercing the speleothems and mobilizing a portion of the polymineralic grains which make up the primary speleothem. There is, thus, a great difference in the ways in which space, on these siliceous deposits, is exploited. The majority of these organisms live on the surface of the speleothem, often sheltered in small 
holes; whereas others, such as the testate amoebae, spend their lives travelling around the speleothem, taking advantage of the slow movement of water or encysting during dry periods; and some mites, like those described in this article, are able to excavate niches in the speleothem in order to complete their life cycles.

\section{ACKNOWLEDGEMENTS}

My sincere thanks to all those people who helped me in this project and several anonymous reviewers for valuable comments.

\section{REFERENCES}

Alexander G.B., Heston W.M. \& Iler R.K., 1954 - The solubility of amorphous silica in water. Journal of the American Chemical Society, 75: 453-455. https://doi.org/10.1021/j150516a002

Apalategui O., Eguiluz L. \& Quesada C., 1990 - Structure of the Ossa Morena Zone. In: Dallmeyer R.D. \& Martinez-García E. (Eds.), Pre-Mesozoic geology of Iberia. Springer, Berlin, p. 280-291.

http://dx.doi.org/10.1007/978-3-642-83980-1 18

Ariño X. \& Saiz-Jimenez C., 1996 - Colonization and deterioration processes in Roman mortars by cyanobacteria, algae and lichens. Aerobiologia, 12: 9-18. https://doi.org/10.1007/BF02248118

Aubrecht R., Brewer-Carias C., Šmída B., Audy M. \& Kováčik L., 2008 - Anatomy of biologically mediated opal speleothems in the world's largest sandstone cave Cueva Charles Brewer, Chimanta Plateau, Venezuela. Sedimentary Geology, 203: 181-195.

https://doi.org/10.1016/j.sedgeo.2007.10.005

Bennett P., Melcer M.E., Siegel D.I. \& Hassett J.P., 1988 - The dissolution of quartz in dilute aqueous solutions of organic acids at $25^{\circ} \mathrm{C}$. Geochimica et Cosmochimica Acta, 52 (6): 1521-1530. https://doi.org/10.1016/0016-7037(88)90222-0

Bennett P., 1991 - Quartz dissolution in organic-rich aqueous solutions. Geochimica et Cosmochimica Acta, 55 (7): 1781-1797.

https://doi.org/10.1016/0016-7037(91)90023-x

Barton H., Suarez P., Muench B., Giarrizzo J., Broering M., Banks E. \& Venkateswaran K., 2009 - The alkali speleogenesis of Roraima Sur Cave, Venezuela. In: White W.B. (Ed.), Proceedings of the $15^{\text {th }}$ International Congress of Speleology, Kerrville, Texas, p. 802-807.

Ehrlich H.L. \& Newman D.K., $2008-$ Geomicrobiology $\left(5^{\text {th }}\right.$ Ed.). Taylor \& Francis, New York, 628 p. https://doi.org/10.1201/9780849379079

Evans G.O., Sheals J.G. \& McFarlane D., 1961 - The terrestrial acari of the British Isles. An Introduction to their morphology, biology and classification, 1. Introduction and biology. Trustees of the British Museum, London, UK, 219 p.

Evans G.O., 1992 - Principles of acarology. C.A.B International, Wallingford, $563 \mathrm{p}$.

Ghezzi D., Sauro F., Zowawi H.M., Hong P., Cappelletti M., Piccini L., Zannoni, D., Vergara F. \& De Waele J.H., 2017 - Exploring the microbial diversity featuring the geochemical complexity of the quartz-sandstone cave Imawarì Yeuta, Auyan Tepui, Venezuela. In: Moore K. $\&$ White S. (Eds.), Proceedings of the $17^{\text {th }}$ International Congress of Speleology, Sydney, p. 385-390.

González L., Vidal-Romaní J.R., López-Galindo M.J., Vaqueiro M., Sanjurjo J., 2013 - First data on testate amoebae in speleothems of caves in igneous rocks. Cadernos do Laboratorio Xeolóxico de Laxe, 37: 37-55.

Hiebert F.K. \& Bennett P.C., 1992 - Microbial control of silicate weathering in organic-rich groundwater. Science, 258: 278-281.

https://doi.org/10.1126/science.258.5080.278

Krantz G.W., 1986 - A Manual of acarology (2 ${ }^{\text {nd }}$ Ed.). Oregon State University, Corvallis, Oregon, 509 p.

Krauskopf K.B., 1967 - Introduction to geochemistry. McGraw-Hill, New York, 721 p.

Kröger N., Deutzmann R., Sumper M., 1999 - Polycationic peptides from diatom biosilica that direct silica nanosphere formation. Science, 286: 1129-1132.

https://doi.org/10.1126/science.286.5442.1129

Lavoie K.H., Northup D.E. \& Barton H.A., 2010 - Microbemineral interactions. In: Sudhir K.J., Khan A.A. \& Rai M.A. (Eds.), Cave microbiology. Science Publishers, p. 1-45.

Leal W.S., Kuwahara Y. \& Suzuki T., 1989 - $\beta$-Acaradial, the sex pheromone of the acarid mite Caloglyphus polyphyllae. Pheromone study of acarid mites XXI. Naturwissenschaften, 76 (7): 332-333. https://doi.org/10.1007/bf00368436

López-Galindo M.J., 2013 - Biometeorización de rocas igneas. Espeleotemas silíceos desde una perspectiva geobiológica. Unpublished PhD Thesis, University of A Coruña, $323 \mathrm{p}$.

Lundberg J., Brewer-Carias C. \& McFarlane D.A., 2010 - Preliminary results from U-Th dating of glacialinterglacial deposition cycles in a silica speleothem from Venezuela. Quaternary Research, 74 (1): 113-120. https://doi.org/10.1016/j.yqres.2010.03.005

Moulds T., 2007 - Subterranean Fauna of the Eneabba, Jurien and South Hill River (Nambung) Karst Areas, Western Australia. Unpublished report for the Department of Environment and Conservation, Midwest Region, $27 \mathrm{p}$. https://doi.org/10.13140/2.1.3416.6089

Northup D.E., Hathaway J.J.M., Snider J.R., Moya M., Garcia M.G., Dapkevicius E., Gabriel C.R., Stone F.D., Spilde M.N. \& Boston P.J., 2013 - Life in Earth's Lava Caves: Implications for Life Detection on Other Planets. In: Hanslmeier A., Kempe S. \& Seckbach J. (Eds.), Life on earth and other planetary bodies. Cellular origin, life in extreme habitats and astrobiology. Springer, Dordrecht, 24: 459-484.

https://doi.org/10.1007/978-94-007-4966-5 26

Northup D.E., Melim L.A., Spilde M.N., Hathaway J.J.M., Garcia M.G., Moya M., Stone F.D., Boston P.J., Dapkevicius M.L.N.E. \& Riquelme C., 2011 - Lava Cave Microbial Communities within Mats and Secondary Mineral Deposits: Implications for Life Detection on Other Planets. Astrobiology. 11 (7): 1-18.

http://doi.org/10.1089/ast.2010.0562

Norton R.A., Bonamo P.M., Grierson J.D. \& Shear W.A., 1988 - Oribatid mite fossils from a terrestrial Devonian deposit near Gilboa. Journal of Paleontology, 62 (2): 259-269.

https://doi.org/10.1017/s0022336000029905

PePeEfe, 2013 - Geological units of the Iberian Peninsula ES, CC BY-SA 3.0.

https://commons.wikimedia.org/wiki/

File:Geological units of the Iberian Peninsula ES.svg

Pérez-Íñigo C., 1993 - Acari, Oribatei, Poronota. In: Ramos M.A. et al. (Eds.) Fauna Ibérica, 3. Museo Nacional de Ciencias Naturales, CSIC, Madrid, 320 p.

Ramírez J., Castelló R. \& Armengot J., 1973 - Mapa Geológico de España, Córdoba Sheet 923. Scale 1:50.000, Geological and Mining Institute of Spain.

Sauro F., Lundberg J., De Waele J., Tisato N. \& Galli E., 2013 - Speleogenesis and speleothems of the 
Guacamaya Cave, Auyan Tepui, Venezuela. In: Filippi M., Bosák P. (Eds.), Proceedings of the $16^{\text {th }}$ International Congress of Speleology, Brno, 2: 298-304.

Summers F.M. \& Witt R.L., 1972 - Nesting behaviour of Cheyletus eruditus (Acarina: Cheyletidae). Pan-Pacific Entomologist, 48 (4): 261-269.

Vidal J.R., Sanjurjo J., Vaqueiro M. \& Fernández D., 2010 - Speleothems of granite caves. Comunicações Geológicas, 97: 71-80.

Vidal-Romaní J.R., Sanjurjo J., Vaqueiro-Rodríguez M., González-López L. \& López-Galindo M.J., 2013 Speleothems in cavities developed in magmatic rocks. In: Filippe M. \& Bosák P. (Eds.), Proceedings of the $16^{\text {th }}$ International Congress of Speleology, Brno, 3: 479-482.

Vidal-Romaní J.R., González-López L., Vaqueiro M. \& Sanjurjo J., 2015 - Bioweathering related to groundwater circulation in cavities of magmatic rock massifs. Environmental Earth Sciences, 73: 2997-3010. https://doi.org/10.1007/s12665-014-3743-2

Walker, L. R. \& Moral, R., 2011 - Primary succession. In: eLS (Ed.), Encyclopedia of life. John Wiley \& Sons, Chichester, p. 1-8. https://doi.org/10.1002/9780470015902.a0003181.pub2

Westall F. \& Cavalazzi B., 2011 - Biosignatures in rocks. In: Reitner J. \& Thiel V. (Eds.), Encyclopedia of geobiology. Springer, Dordrecht, p. 189-201.

https://doi.org/10.1007/978-1-4020-9212-1_36

Whitton B.A., 1992 - Diversity, Ecology, and Taxonomy of the Cyanobacteria. In: Mann N.H. \& Carr N.G. (Eds.), Photosynthetic Prokaryotes. Biotechnology handbooks. Springer, Boston, 6: 1-51. https://doi.org/10.1007/978-1-4757-1332-9 1

Wray R.A., 1997 - The formation and significance of coralline silica speleothems in the Sydney Basin, southeastern Australia. Physical Geography, 18: 1-16. https://doi.org/10.1080/02723646.1997.10642603

Wray R.A., 1999 - Opal and chalcedony speleothems on quartz sandstones in the Sydney region, southeastern Australia. Australian Journal of Earth Sciences, 46 (4): 623-632.

https://doi.org/10.1046/j.1440-0952.1999.00732.x

Wray R.A. \& Sauro F., 2017 - An updated global review of solutional weathering processes and forms in quartz sandstones and quartzites. Earth-Science Reviews, 171: 520-557.

https://doi.org/10.1016/j.earscirev.2017.06.008

Zacharda M., 1978 - Ecology of Rhagidiidae. In: Rodríguez J.G. (Ed.), Recent advances in acarology I. Academic Press, New York, p. 537-542.

https://doi.org/10.1016/b978-0-12-592201-2.50076-2 